\title{
Water reclamation for industrial use in sub-Saharan Africa - a critical review
}

\author{
Noor Jehan Gulamussen ${ }^{1,2}$, André Marques Arsénio ${ }^{1}$, Nelson Pedro Matsinhe ${ }^{2}$, and \\ Louis Cornelis Rietveld ${ }^{1}$ \\ ${ }^{1}$ Faculty of Civil Engineering and Geosciences, Delft University of Technology, \\ P.O. Box 5048, 2600 GA Delft, the Netherlands \\ ${ }^{2}$ Faculty of Engineering, Eduardo Mondlane University, P.O. Box 257, Maputo, Mozambique
}

Correspondence: Noor Jehan Gulamussen (n.j.gulamussen@tudelft.nl)

Received: 29 June 2018 - Discussion started: 4 September 2018

Revised: 25 June 2019 - Accepted: 16 July 2019 - Published: 1 October 2019

\begin{abstract}
The increasing world population and growth of industrial development lead to growing water scarcity that, combined with deficient sanitation services, represents serious challenges, particularly in regions like subSaharan Africa. Water reclamation is a promising approach to reduce water scarcity, serving as a driving force for better sanitation services and protecting the environment by treating sewage and redistributing for the benefit of other water-dependent applications (e.g., industries).

This paper aims to give an overview of the global trends on water reclamation, with a focus on industrial use, and to derive lessons for implementation of water reclamation projects in sub-Saharan Africa. Findings show that extensive experience exists in technology and management practices that can allow successful implementation of water reclamation projects in the region. Under the conditions of deficient sanitation services and low levels of technical expertise, the main challenge is to develop a framework that can facilitate the integration of social and technological methodologies and help in introducing water reclamation in water allocation planning, including the development of specific legislation for industrial water use and disposal.
\end{abstract}

\section{Introduction}

The importance of water reclamation as a way of supplementing water supply needs, improving sanitation services through wastewater treatment and disposal, and maintaining a sustainable environment is commonly acknowledged (Kennedy and Tsuchihashi, 2005; Lazarova et al., 2012, 2013; Miller, 2006; Yerri and Piratla, 2019). The use of reclaimed water increases the total available water supply, substituting drinking water where appropriate (Asano, 2005) and preserving the health of waterways, wetlands, flora and fauna (Asano, 2005; Toze, 2006). In addition, reclaimed water, originating from sewage, contains nutrients; thus, if this water is used to irrigate agricultural land, less fertilizer is required for crop growth, therefore reducing the level of nutrients and other pollutants entering waterways and sensitive marine environments (Cornejo et al., 2016; Sapkota, 2019; Eslasmain, 2016; Toze, 2006). Furthermore, reclaimed water can often be found near the point of use, reducing pumping costs and eliminating the need to negotiate with neighboring countries for increased water supplies (Lee and Tan, 2016; Smith, 2011). Using reclaimed water, scarcity, environmental pollution and human-health issues can be addressed and can positively impact the quality of the urban environment and lead to improved urban health (Rietveld et al., 2016; Salgot and Folch, 2018). There are a wide variety of water reclamation applications, including irrigation, industry water supply, non-potable urban uses, environmental and recreational enhancement, and even direct consumption (Angelakis and Gikas, 2014; Lazarova et al., 2012; Van der Bruggen, 2010; USEPA, 2012).

The global practice of water reclamation in the world is growing (Chhipi-Shrestha et al., 2019); the global reclamation capacity was projected to have increased from $33.7 \times$ $10^{6} \mathrm{~m}^{3} \mathrm{~d}^{-1}$ in 2010 to $54.5 \times 10^{6} \mathrm{~m}^{3} \mathrm{~d}^{-1}$ in 2015 (Eslasmain, 
2016). Case studies also show that significant advances in water reclamation have occurred in arid regions including Australia, China, Mediterranean countries, the Middle East, and the US (Lazarova et al., 2013). In temperate regions, water reclamation is characterized by fast development in particular for industrial applications and in environmental and urban water reclamation (Lazarova et al., 2013; Rietveld et al., 2011; Van Agtmaal et al., 2007).

The expansion of water reclamation on the global scale has been driven by multiple factors: pressure on water resources derived from climate change (Nazari et al., 2012; Jiménez et al., 2010); water stress derived from population growth and, consequently, growth of cities that challenge the water resources and sanitation systems (Lautze et al., 2014); environmental and economic concerns that limit the use of other solutions to combat water scarcity, such as long-distance water transfer, construction of large dams and desalination (GWI, 2010); and increased confidence in and reduced costs of membrane and disinfection technologies, which provide assurance of the safety of reclaimed water blended into reservoirs or aquifers for potable uses (GWI, 2010).

In high-income countries, the total water usage for industry corresponds to $41 \%$ of the total water demand, while in low-income countries, only $3 \%$ is used for industry (World Bank, 2015). Although the industrial withdrawal tends to rise, estimated at $1.9 \times 10^{9} \mathrm{~m}^{3} \mathrm{~d}^{-1}$ in 1995 to about $3.2 \times$ $10^{9} \mathrm{~m}^{3} \mathrm{~d}^{-1}$ by 2025 (Holden, 2013), the rate of increase will slow down as the industries adopt water-saving and waterrecycling practices. Globally, $20 \%$ of reclaimed water is used in industrial applications, competing with agriculture (70\%) and municipal (10\%) uses (GWI, 2010; Lautze et al., 2014).

Industrial water use can be grouped as cooling, boiler feed and process water (Visvanathan, 1999). The uses are very diverse and include washing and rinsing, equipment operation, product transport, manufacturing and construction activities (Lautze et al., 2014; Vigneswaran and Sundaravadivel, 2009). Although cooling water is the most water-demanding process in industry (EUROSTAT, 2014), with two-thirds of all industrial water being used for cooling (Lens et al., 2002), the percentage of reduction by using reclaimed water largely depends on the demand of the recirculating cooling system (Hunter, 2001).

Despite the great application potential in terms of water needs (Almeida et al., 2013), the market for reclaimed water for industry is still awaiting a wider implementation (Ordóñez et al., 2014). Information about the means, methods and technologies for implementing water reclamation best practices in industry exists and is well known (Emanuel, 2010; NWRS, 2011), and this information can be used to define and refine technical water reclamation solutions in subSaharan Africa (WBCSD - IWA, 2009). Therefore, water reclamation for industrial use is reviewed herein, considering the global trends, water flow and quality requirements for different uses, and the possibility of using reclaimed water as an alternative for fresh surface or groundwater for industries in sub-Saharan Africa.

\section{Global trends in water reclamation for industrial use}

\subsection{Driving forces for water reclamation}

Water reclamation for industries is mostly driven by low availability of local water, either due to limited sources of water or intense competition for supply. Both factors are sometimes reflected by high industrial water tariffs (JiménezCisneros, 2014). However, the major factors limiting the use of reclaimed water in industry are, among others, ensuring continuous operation without resulting in water shortage, meeting quality standards, producing at acceptable costs and acceptability of the use of reclaimed water by industries (Toze, 2006; Ordóñez et al., 2014).

The dynamics of water reclamation for industrial use are also influenced by factors such as economic development priorities, environmental and climatic factors, social acceptance, and availability of financial resources (Lautze et al., 2014). Table 1 presents general drivers for and main applications of water reclamation for industrial use in different regions of the world. In developed countries, aside from water scarcity, water reclamation for industrial use is driven by environmental concerns, with sewage treatment plant effluent typically utilized for purposes such as cooling, boiler feeds, condensing and steam production, firefighting, and dust mitigation; in developing countries water reclamation is primarily driven by water scarcity.

These drivers can thus be connected not only to the socioeconomic context in which the projects are executed but also to governmental support, public-private partnerships (PPPs), stakeholder involvement, savings in water needs, and economic and environmental benefits.

\subsection{Socioeconomic and political context}

The regional variations in water reclamation indicate that most projects, executed in industry, are centered in developed countries, where water use for industries is higher than in developing countries. There are a number of conditions in developing countries that impact the potential for water reclamation, such as lack of wastewater collection and inadequate treatment systems (Bendahmane, 1992). Despite this, severe water shortages and growing interest in ecological systems have led the city of Durban, South Africa, to implement water reclamation for several demanding industries (Dereschel et al., 1998; Eckart et al., 2011).

Establishing effective and equitable management practices requires knowledge, expertise, and investment at political, institutional and technical levels. In cases where governments were committed to minimize water shortage or protect the environment, the projects were successful (Lautze et al., 
Table 1. Regional variation in water reclamation for industrial application.

\begin{tabular}{|c|c|c|c|}
\hline Region & Drivers & Main application(s) & References \\
\hline $\begin{array}{l}\text { Northern } \\
\text { Europe }\end{array}$ & $\begin{array}{l}\text { - High industrial water demand } \\
\text { in highly populated areas } \\
\text { - Resource efficiency } \\
\text { - Environmental concerns }\end{array}$ & Cooling & $\begin{array}{l}\text { (Asano and Jimenez, 2008; USEPA, 1992; } \\
\text { Ryan, 2016; Marecos do Monte, } \\
\text { 2007; Angelakis and Gikas, 2014) }\end{array}$ \\
\hline $\begin{array}{l}\text { North } \\
\text { America }\end{array}$ & $\begin{array}{l}\text { - Water scarcity } \\
\text { - Cost effectiveness of reclaimed } \\
\text { water and resource efficiency } \\
\text { - Environmental concerns }\end{array}$ & $\begin{array}{l}\text { Process water, cooling, } \\
\text { condensing and steam } \\
\text { generation }\end{array}$ & $\begin{array}{l}\text { (Asano and Jimenez, 2008; USEPA, } \\
\text { 1992; Schaefer et al., 2004; Smith, } \\
\text { 2015) }\end{array}$ \\
\hline Asia & $\begin{array}{l}\text { - Water scarcity } \\
\text { - Political pressure }\end{array}$ & $\begin{array}{l}\text { Cooling, washing and } \\
\text { process water }\end{array}$ & $\begin{array}{l}\text { (Asano and Jimenez, 2008; Indian } \\
\text { Institutes of Technology, 2011; USEPA, 1992) }\end{array}$ \\
\hline Australia & $\begin{array}{l}\text { - Water scarcity } \\
\text { - Environmental concerns }\end{array}$ & $\begin{array}{l}\text { Cooling, boiler feed, } \\
\text { firefighting and dust } \\
\text { suppression }\end{array}$ & $\begin{array}{l}\text { (Asano and Jimenez, 2008; USEPA, } \\
\text { 1992; Apostolidis et al., 2011) }\end{array}$ \\
\hline $\begin{array}{l}\text { Southern } \\
\text { Africa }\end{array}$ & - Water scarcity & $\begin{array}{l}\text { Cooling, mining and } \\
\text { process water }\end{array}$ & (Indian Institute of Technology, 2011) \\
\hline
\end{tabular}

2014; Lazarova et al., 2013). Some actions required the development and application of regulatory actions with stringent influent requirements and tariffs to force industries to implement new technologies and strategies to use reclaimed water (Grobicki, 2008).

The city of Sydney experienced three severe droughts in the last two centuries, which challenged the government to improve the understanding of the potential impacts of climate change on water availability and demand. As a result, the city conducted studies in order to increase water reclamation and reduce demand (Water for Life, 2006).

In order to reduce the dependence on water imported from neighboring Malaysia, the government of Singapore secured the availability of funds and incentives for industries that use reclaimed water (Lee and Tan, 2016; PUB, 2014).

The state of Karnataka, India, also faces water shortages due to population growth and expansion of industrial activities (Government of Karnakata, 2012). Therefore, the state government planned the implementation of subsidies for up to $75 \%$ of the cost of equipment for water reclamation by "small and medium manufacturing enterprises" (Freedman and Enssle, 2015; Government of Karnakata, 2012).

\subsection{Public-private partnerships and stakeholder involvement}

One particular challenge is to reconcile the need for tariffs that encourage the use of reclaimed water with availability of financing for water reclamation projects (Molinos-Senante et al., 2013). PPPs can offer a combination of cost and performance benefits that municipal and industrial clients require (Lloyd Owen, 2016). Lloyd Owen (2016), having evaluated 2714 water projects, noted the existence of 72 wa- ter reclamation projects (for all applications) in 2014 under PPPs covering 29.44 million people, with a total capacity of $11.80 \times 10^{6} \mathrm{~m}^{3} \mathrm{~d}^{-1}$ and more than half of the projects being located in areas of high water stress.

The integration of all relevant institutions and stakeholders in the planning and design of water reclamation projects can reduce the risk of failure and increase the cost effectiveness of the projects (Lautze et al., 2014; Giurco et al., 2010). Lloyd Owen (2016) also showed that water reclamation projects had not ended before the deadline, which is in contrast to general water projects, indicating the complexity of implementing water reclamation schemes. Therefore, water reclamation opportunities must be identified and cost efficiencies optimized by the stakeholders' involvement through synergy development and exploration of cogeneration opportunities. If the end users' preferences are not considered during the planning phase, they may simply reject the plan, not be able to make full use of the provided water or refuse to pay for the service (Lautze et al., 2014).

Historical survey data consistently show that the public tolerates and welcomes non-potable use of reclaimed water, particularly when there is lower risk of human contact; e.g., high levels of public acceptance of non-potable water use in industrial processing have been reported (Chen et al., 2015). Examples can be found in Australia and California, where the success is credited to the commitment of the projects in informing and educating the local community about the efficient water use and reclamation, thus creating a greater awareness on water shortage problems (Po et al., 2003). 


\subsection{Savings in water needs and economic, health and environmental benefits}

Water reclamation for industry often produces considerable savings in fresh water and produces economic and environmental benefits (Lahnsteiner and Klegraf, 2005; UNEP, 2005).

In the city of St. Petersburg, Florida (USA), all wastewater is treated to a high standard. The reclaimed water is then used for irrigation and industrial cooling applications by thousands of customers, accounting for nearly half of the city's water needs. By substituting the potable water, the city has eliminated the need for expansion of its potable water supply system until the year 2030, with cost savings of about USD 30 million (Grobicki, 2008; Lazarova et al., 2012).

By using reclaimed water, Durban industries reduced the costs of water supply; in particular, the Mondi paper mill saves an amount equivalent to EUR 3.5 million per year. The project allowed Durban Metro Water Services to install and operate a new affordable distribution network for the townships while offering the industry cheap and high-quality water (BIO by Deloitte, 2015).

The Panipat Refinery in India enabled its expansion by implementing water reclamation, increasing the economic activity. The cost saving, by using reclaimed water, was EUR 5000-12 400/year, and the water demand decreased by $16000 \mathrm{~m}^{3} \mathrm{~d}^{-1}$. In addition, it had a positive environmental impact by reducing freshwater withdrawal by $7000 \mathrm{~m}^{3} \mathrm{~d}^{-1}$ and by not discharging the sewage in the Yamuna Canal (Anderson, 2003; Lazarova et al., 2013).

Another example is Dow Benelux's site at Terneuzen (the Netherlands). The effluent of the sewage treatment plant is treated by membrane filtration and used by the industry to generate steam, resulting in savings not only in water for domestic uses but also energy, with $65 \%$ less energy consumed at the facility compared to desalination of the same amount of seawater. These savings are equivalent to a decrease in $\mathrm{CO}_{2}$ emission of $5000 \mathrm{t} \mathrm{yr}^{-1}$ (Baker, 2008).

Discharge of untreated sewage can lead to adverse health effects. Besides the economic and environmental benefits, by using reclaimed water in industry, also negative public health effects are prevented (Kerstens et al., 2016).

\section{Water use in industry}

\subsection{Water flow in industry}

In the period of 1997-2002, the water consumption by industries, in $10^{9} \mathrm{~m}^{3} \mathrm{~d}^{-1}$, was 26.6 in Africa, 697.0 in Asia and the Pacific, 556.4 in Europe, 75.3 in Latin America and the Caribbean, and 670.1 in North America, respectively. In Africa, only $5 \%$ of the total water use was industrial, whereas in sub-Saharan countries it was only $2 \%$ $\left(12.1 \times 10^{6} \mathrm{~m}^{3} \mathrm{~d}^{-1} ;\right.$ Institute Water for Africa, 2016).
The most water-demanding industries and their applications per tonne of product can be found in Table 2 .

Thermoelectric power generation typically requires large quantities of cooling water, representing a major opportunity for reclaimed water, providing that corrosion, biological and scaling concerns are addressed. There are also opportunities for the use of reclaimed water in various production steps of some industries such as pulp and paper, chemical, textile, construction, petroleum and coal.

\subsection{Water quality needs and required treatment for use of reclaimed water in non-food industry}

Food industries require potable water even for cleaning purposes (Meneses et al., 2017). Treating sewage to potable quality requires advanced technology (Li et al., 2015) that, in most cases, is not available in developing countries (Bouabid and Louis, 2015). Furthermore, the public tends to be more skeptical towards the use of reclaimed water in food industries (Chen et al., 2015). Therefore, the focus of this paper is on non-food applications.

The main concern related to water quality, principally for boiler feed and cooling water, is the formation of precipitated impurities (scaling), corrosion, biological growth, fouling and foaming. For this reason, industrial water for cooling and boiler feed should have a low hardness level, a low salt and suspended solids' concentration, low organic matter and nutrients, and in some cases, the absence of pathogenic microorganisms. The industrial water reclamation concerns and potential treatment processes are presented in Table 3.

\subsubsection{Cooling water requirements}

Cooling is utilized for the operation of pumps and compressors vacuum systems and steam turbine condensers (Hunter, 2001). Cooling systems can have different configurations but are mainly divided into once-through and recirculating systems.

Once-through cooling systems transfer heat to water to cool the process equipment and then discharge the hot water after a single use (Asano and Jiménez, 1998). This system requires a large volume of water, but the quality requirements are generally not restrictive, and usually lake water, river water and seawater is used with little or any treatment (Lens et al., 2002). The use of disinfected reclaimed water is also a convenient alternative whenever the industries are located near a wastewater outfall (USEPA, 2004; National Academy, 2012).

Recirculating cooling systems transfer the heat from the warmed water to the vapor so that the water can be reused to absorb process heat and recirculated for additional cycles (San Jose Environmental Service Department, 2002). Hot water is pumped at the top of the tower and released over packing material, where it is cooled when in contact with the cold air (Lens et al., 2002). The resulting hot moist air is 
Table 2. Industrial water consumption for the most water-demanding industries. Adapted from Hunter (2001), Ranade and Bhandari (2014), Joint Research Council (2001), European Commission (2003), and Cooperman et al. (2012).

\begin{tabular}{lll}
\hline Type of industry & Consumption & Most water-demanding applications \\
\hline Thermal power plant & $1.8 \mathrm{~m}^{3} \mathrm{~h} \mathrm{MW}^{-1}$ & Cooling \\
Paper & $300-1000 \mathrm{~m}^{3}$ per tonne of product & Cooling and boiler feed \\
Petroleum & $10-300 \mathrm{~m}^{3}$ per tonne of product & Cooling \\
Chemical fertilizer & $270 \mathrm{~m}^{3}$ per tonne of product & Cooling \\
Iron and steel & $20-60 \mathrm{~m}^{3}$ per tonne of product & Cooling \\
Mining & $40 \mathrm{~m}^{3}$ per tonne of ore & Process \\
Sugar & $15 \mathrm{~m}^{3}$ per tonne of sugar & Cooling \\
Textile & $2-6 \mathrm{~m}^{3}$ per tonne of greasy wool & Cooling and process \\
\hline
\end{tabular}

Table 3. Industrial water reclamation concern and potential treatment (sources: Asano, 1998; Cisneros, 2014; USEPA, 1992).

\begin{tabular}{llll}
\hline Concern & Problem description & Cause & Treatment process \\
\hline Scaling & $\begin{array}{l}\text { Hard deposits formed in cooling sys- } \\
\text { tems that reduce the efficiency of the } \\
\text { heat exchanger }\end{array}$ & $\begin{array}{l}\text { Inorganic com- } \\
\text { pounds such as } \\
\text { calcium, magnesium } \\
\text { and silica }\end{array}$ & $\begin{array}{l}\text { Chemicals for acidification, EDTA and } \\
\text { polymeric inorganic phosphate, } \\
\text { lime softening, and ion exchange }\end{array}$ \\
\hline Corrosion & $\begin{array}{l}\text { Corrosion by increase in electrical con- } \\
\text { ductivity, acidic conditions, and the } \\
\text { presence of dissolved gases and certain } \\
\text { metals with high oxidation state }\end{array}$ & $\begin{array}{l}\text { Dissolved solids, } \\
\mathrm{pH} \text { and } \\
\text { ammonia }\end{array}$ & $\begin{array}{l}\text { Corrosion inhibitors such as chro- } \\
\text { mates, polyphosphates, zinc and } \\
\text { polysilicates }\end{array}$ \\
\hline $\begin{array}{l}\text { Biological } \\
\text { growth }\end{array}$ & $\begin{array}{l}\text { Growth of microorganisms, reducing } \\
\text { heat transfer efficiency and water flow; } \\
\text { formation of corrosive by-products }\end{array}$ & $\begin{array}{l}\text { Organic residues, } \\
\text { suspended solids, } \\
\text { ammonia and } \\
\text { phosphorus }\end{array}$ & $\begin{array}{l}\text { Biocides such as chlorine, sodium } \\
\text { hypochlorite and chlorine dioxide, and } \\
\text { filtration }\end{array}$ \\
\hline Clogging & $\begin{array}{l}\text { Formation and settling of particulate } \\
\text { matter that clogs equipment }\end{array}$ & $\begin{array}{l}\text { Suspended solids } \\
\text { and precipitates }\end{array}$ & $\begin{array}{l}\text { Coagulation and } \\
\text { filtration }\end{array}$ \\
\hline
\end{tabular}

released into the atmosphere, while the cooled water is collected into a reservoir at the bottom of the cooling tower, where it is returned into the recirculating system (Lens et al., 2002). In recirculating cooling systems, additional treatment, such as filtration, chemical precipitation, ion exchange or reverse osmosis, can be necessary to avoid scaling (Asano and Jiménez, 1998). In some cases, only additional chemical treatment is necessary, e.g., to avoid foaming, to control corrosion, to disperse suspended solids or to control biological growth (National Academy, 2012).

\subsubsection{Boiler feed water requirements}

Water to be used for boiler feed requires extensive treatment, with the quality requirements increasing with the operating pressure of the boiler. The water needs to be treated to remove inorganic constituents such as calcium, magnesium, silica and aluminium that contribute to scale formation in boilers. Treatment should also control excessive alkalinity and high concentrations of potassium and sodium that can cause foaming as well as bicarbonate alkalinity that can lead to the release of carbon dioxide, which can increase the acidity in the steam and corrode the equipment (National Academy, 2012). To prevent corrosion, chloride, sulfate and sodium should be lower than $5 \mathrm{mg} \mathrm{L}^{-1}$ (Moed, 2015). Organics in reclaimed water can also cause foam and corrosion in boilers, which can be controlled by carbon adsorption, ion exchange or corrosion inhibitors such as amines (USEPA, 2012; Sensorex, 2016; Moed, 2015).

\subsubsection{Process water requirements}

Process water is needed for processes such as quenching reactions and washing (Lens et al., 2002). For mineral wash and transport in mineral and mining industries, the required treatment involves the removal of suspended solids and some organics. Secondary sewage treatment plant effluent may be acceptable for applications such as concrete manufacturing, but advanced treatment is needed for applications such as carpet dyeing because water used in textile manufacturing must be non-staining and organic matter could compromise the quality of the final product. Divalent metal cations cause 
problems in some of the dyeing processes that use soap, and nitrates and nitrites may also cause problems because of structural modification in azo dyes (National Academy, 2012). Other industrial process uses require high-quality water, e.g., water used to wash circuit boards in the electronics industry often requires reverse osmosis treatment for extensive salt removal.

More specific examples of treatment requirements for process water in industries can be seen in Table 4 .

\subsection{Cost comparison of treatment technology options for water reclamation}

Most of the existing water reclamation schemes use effluent from the secondary sewage treatment processes for further purification in tertiary or advanced treatment units (Table 4), resulting in additional costs for installation and operation. Other constraints, such as land acquisition for building sites, distance between the production site and the consumers, and requirement to install a dual distribution system or retrofitting, also highly influence the capital and operation and maintenance costs. The separate distribution system can involve more than $70 \%$ of the overall costs for reclamation, depending on site-specific conditions (Lazarova, 2005).

Among the tertiary treatments, polishing pond treatment is the most simple and unsophisticated but has proven to be a competitive, efficient solution for small aggregates (project size flow of $3000 \mathrm{~m}^{3} \mathrm{~d}^{-1}$ and 15000 population equivalent; Lazarova, 2005). The construction of filtration as a tertiary treatment unit results in a 2- to 3-fold increase in the capital and operating costs compared to the disinfection processes. For project sizes more than $7500 \mathrm{~m}^{3} \mathrm{~d}^{-1}$ (50 000 population equivalent), the costs for UV treatment or chlorination for disinfection become comparable to maturation ponds. The cost difference between UV irradiation and ozonation decreases with plant size. For disinfection processes, the variable costs are high compared to the fixed costs, e.g., for UV irradiation, the variable costs associated with lamp replacement and cleaning are about $45 \%-50 \%$ of the total annual costs (Indian Institute of Technology, 2011), while variable costs associated with chemical use can increase up to $50 \%-$ $70 \%$ for chlorination and ozonation, respectively, for small to large water reclamation schemes (Lazarova, 2005). Use of secondary to tertiary processes for treatment of sewage to a high level for water reclamation can be energy intensive. Energy costs are only about $2 \%-5 \%$ of the variable costs for chlorination but can be $15 \%$ and $35 \%$ of the total variable costs for UV irradiation and ozonation, respectively (Indian Institute of Technology, 2011).

The costs of membrane filtration (micro- and ultrafiltration) are significantly higher compared to the other disinfection processes. The widespread application of membrane bioreactors (MBRs), despite all the process advantages, is constrained by the high costs of membranes aside from high operation and maintenance costs due to fouling but has as an advantage in terms of treatment performance. Compared to the conventional activated sludge process, the overall costs for membrane bioreactors are up to $20 \%$ and $50 \%$ higher, depending on plant size (Indian Institute of Technology, 2011).

\section{Water scarcity in sub-Saharan Africa}

Water scarcity in sub-Saharan Africa is highly influenced by increased demand (UN WATER/AFRICA, 2009); insufficient water resource management, including water losses due to poor operation and maintenance, below-cost recovery tariffs, and low collection rates (IMF, 2015); a lack of infrastructure, financial resources and skills (UN WATER/AFRICA, 2009); and climate change (Conway et al., 2015).

\subsection{Water availability and climate change}

Sub-Saharan Africa has an abundance of water year-round in the humid and semi-humid parts of central Africa (UN WATER/AFRICA, 2009). However, many sub-Saharan African countries have relatively limited access to water resources (IMF, 2015). In the large semi-arid and arid areas of the southern sub-region, there is an unpredictable temporal and spatial variability in rainfall (Van Koppen, 2003; UN WATER/AFRICA, 2009). Great disparities also exist within countries - whereas in northern-central Mozambique the precipitation is almost $2000 \mathrm{~mm} \mathrm{yr}^{-1}$, it is less than $800 \mathrm{~mm} \mathrm{yr}^{-1}$ in the southern region (Tadross and Johnston, 2012), with all rainfall being restricted to the period between November and April. Due to high rates of evaporation, in the southern part of Africa, renewable water resources - average availability of surface water and groundwater - constitute only $9 \%$ of the total water available (AMCOW, 2012). Furthermore, historical data show that in the past 20 years, available freshwater resources in Africa have greatly decreased due to severe and prolonged droughts (Donkor and Wolde, 2001). Also, several countries report that the quality of water resources is deteriorating due to pollution resulting from industries, urban runoff, sewerage and agro-chemicals (IMF, 2015; Donkor and Wolde, 1999).

Climate change poses an additional threat to water security in sub-Saharan Africa; changes in precipitation and temperature may lead to changes in water availability due to the fact that annual precipitation, soil moisture and runoff are likely to decrease while temperature increases evaporative demand (Conway et al., 2015). In addition, it is expected that rainfall will drop by $10 \%$ by 2050 , leading to major water shortages (de Wit, 2006). According to most climate models, many southern African countries will warm up more than the global mean, with annual mean temperature rising by 2 to $3^{\circ} \mathrm{C}$ in most cases (Conway et al., 2015). 
Table 4. Examples of industries that use reclaimed water. RO is reverse osmosis, UF is ultrafiltration and IEX is ion exchange.

\begin{tabular}{|c|c|c|c|c|c|}
\hline Industry & $\begin{array}{l}\text { Country } \\
\text { (company) }\end{array}$ & $\begin{array}{l}\text { Reclamation } \\
\text { application }\end{array}$ & Water source & Treatment technology & Reference \\
\hline \multirow[t]{2}{*}{ Power plant } & $\begin{array}{l}\text { Turkey } \\
\text { Mexico } \\
\text { (Villa de } \\
\text { Reyes) }\end{array}$ & $\begin{array}{l}\text { Boiler feed } \\
\text { and cooling }\end{array}$ & $\begin{array}{l}\text { Sewage } \\
\text { and wastewa- } \\
\text { ter }\end{array}$ & $\begin{array}{l}\text { UF, activated carbon filter, RO, and IEX } \\
\text { screening and advanced primary treat- } \\
\text { ment; secondary treatment by activated } \\
\text { sludge with } \mathrm{N} \text { removal; and tertiary treat- } \\
\text { ment with lime softening, sand filtration, } \\
\text { IEX and chlorine disinfection }\end{array}$ & $\begin{array}{l}\text { (Tanik et al., 1996) } \\
\text { (Lazarova et al., } \\
\text { 2013) }\end{array}$ \\
\hline & $\begin{array}{l}\text { US, Texas } \\
\text { (Palo } \\
\text { Verde } \\
\text { Nuclear) }\end{array}$ & Cooling & Sewage & $\begin{array}{l}\text { Secondary treatment followed by biolog- } \\
\text { ical nitrification, lime and soda ash ad- } \\
\text { dition for softening and phosphorus re- } \\
\text { moval, filtration and chlorination }\end{array}$ & $\begin{array}{l}\text { (Asano and Vis- } \\
\text { vanathan, 2001) }\end{array}$ \\
\hline \multirow[t]{2}{*}{ Petrochemical } & $\begin{array}{l}\text { India } \\
\text { (Panipat) }\end{array}$ & Boiler feed & $\begin{array}{l}\text { Industrial } \\
\text { wastewater }\end{array}$ & $\begin{array}{l}\text { Solid-contact clarification; pressure sand } \\
\text { filtration; and UF, RO and IEX in mixed- } \\
\text { bed filters }\end{array}$ & $\begin{array}{l}\text { (Lahnsteiner and } \\
\text { Mittal, 2010) }\end{array}$ \\
\hline & $\begin{array}{l}\text { California } \\
\text { (RARE) }\end{array}$ & $\begin{array}{l}\text { Boiler feed } \\
\text { and cooling }\end{array}$ & Sewage & $\begin{array}{l}\text { Secondary effluent is pretreated by } \mathrm{MF} \\
\text { and then treated by } \mathrm{RO}\end{array}$ & $\begin{array}{l}\text { (Lazarova et al., } \\
\text { 2013) }\end{array}$ \\
\hline \multirow[t]{2}{*}{ Refinery } & $\begin{array}{l}\text { US } \\
\text { (Chevron } \\
\text { under } \\
\text { ECLWRF) }\end{array}$ & Boiler feed & Sewage & Secondary effluent treated by RO & (GWI, 2010) \\
\hline & $\begin{array}{l}\text { India } \\
\text { (Madras } \\
\text { refinery) }\end{array}$ & $\begin{array}{l}\text { Boiler make- } \\
\text { up }\end{array}$ & Wastewater & $\begin{array}{l}\text { Additional secondary biological treat- } \\
\text { ment, chemically aided settling, pres- } \\
\text { sure filtration, ammonia stripping, car- } \\
\text { bonation, clarification, pressure filtration, } \\
\text { chlorination, sodium bisulfate dosing, } \\
\text { multimedia filtration, cartridge filtration } \\
\text { and RO }\end{array}$ & $\begin{array}{l}\text { (Indian Institutes of } \\
\text { Technology, 2011; } \\
\text { Lahnsteiner and } \\
\text { Mittal, 2010) }\end{array}$ \\
\hline \multirow[t]{3}{*}{$\begin{array}{l}\text { Pulp and pa- } \\
\text { per }\end{array}$} & $\begin{array}{l}\text { South } \\
\text { Africa } \\
\text { (Mondi } \\
\text { paper mill) }\end{array}$ & $\begin{array}{l}\text { Cooling and } \\
\text { process water }\end{array}$ & $\begin{array}{l}\text { Industrial } \\
\text { wastewater }\end{array}$ & UF, IEX and RO & $\begin{array}{l}\text { (Visvanathan and } \\
\text { Asano, 1999) }\end{array}$ \\
\hline & $\begin{array}{l}\text { Brazil } \\
\text { (Indústria } \\
\text { CPBR) }\end{array}$ & $\begin{array}{l}\text { Cooling and } \\
\text { process water }\end{array}$ & Wastewater & Tertiary UF system & (Kossar, 2013) \\
\hline & $\begin{array}{l}\text { China } \\
\text { (Taian } \\
\text { Baichuan } \\
\text { Paper) }\end{array}$ & Cooling & Wastewater & $\begin{array}{l}\text { Two-stage activated sludge plant with ter- } \\
\text { tiary sand filtration and chlorination }\end{array}$ & $\begin{array}{l}\text { (Lahnsteiner and } \\
\text { Klegraf, 2005) }\end{array}$ \\
\hline $\begin{array}{l}\text { Wafer fabrica- } \\
\text { tion }\end{array}$ & $\begin{array}{l}\text { Singapore } \\
\text { (Fabs) }\end{array}$ & $\begin{array}{l}\text { Cooling and } \\
\text { process water }\end{array}$ & Sewage & MF, RO and UV & (PUB, 2014) \\
\hline Chemical & $\begin{array}{l}\text { Germany } \\
\text { (DuPont } \\
\text { production } \\
\text { center) }\end{array}$ & $\begin{array}{l}\text { Process water } \\
\text { for fiber pro- } \\
\text { duction and } \\
\text { boiler feed } \\
\text { water }\end{array}$ & $\begin{array}{l}\text { Industrial } \\
\text { wastewater }\end{array}$ & $\begin{array}{l}\text { Biological pre-treatment including nitro- } \\
\text { gen and phosphorous removal and then } \\
\text { tertiary filtration with UF, activated car- } \\
\text { bon adsorption, UV, RO and IEX }\end{array}$ & $\begin{array}{l}\text { (Lahnsteiner and } \\
\text { Klegraf, 2005) }\end{array}$ \\
\hline
\end{tabular}




\subsection{Water demand}

Water demand in Africa has been increasing as a consequence of rapid population growth (UN WATER/AFRICA, 2009), expanding urbanization (World Bank, 2011) and increased economic development (UN WATER/AFRICA, 2009). In the continent, industrial water demand represents $6 \%$ of the total water withdrawal, followed by domestic demand with $9 \%$ and agriculture with $85 \%$ (AMCOW, 2012). Most water demand from industries in sub-Saharan Africa countries comes from mining and metallurgy, particularly smelting and refining. For example, In Mozambique, coal mining was estimated to produce 8.42 million tonnes (Yager, 2016), which can be translated into a total water consumption of $0.55-1.36 \times 10^{6} \mathrm{~m}^{3} \mathrm{~d}^{-1}$ (Table 2). Electricity production from thermal power plants ( $66 \mathrm{GW}$; Jingura and Kamusoko, 2017) in sub-Saharan Africa is estimated to consume around $2.85 \times 10^{6} \mathrm{~m}^{3} \mathrm{~d}^{-1}$ (Table 2), whereas sugar production was estimated at 760 million tonnes in 2013 (Hess et al., 2016); the water involved in production, not including irrigation, was equivalent to $312.33 \times 10^{6} \mathrm{~m}^{3} \mathrm{~d}^{-1}$ (Table 2). This development of more water-intensive activities has put stress on existing water infrastructure (IMF, 2015), and this is expected to increase in the near future (Holden, 2013).

\subsection{Water resource management}

All continental sub-Saharan African countries share at least one international water basin (UN WATER/AFRICA, 2009), and often this situation leads to disputes, with the downstream countries being the most affected (Ashton, 2003).

Extensive upstream usage of the Umbeluzi and Incomati rivers for irrigation and industrial use in South Africa and Swaziland have impacted water supply to the city of Maputo, the capital of Mozambique (Van der Watt, 2003). A very similar situation is also encountered at the Limpopo River, where excessive abstraction, $1.173 \times 10^{6} \mathrm{~m}^{3}$ in 1980 and $1.723 \times 10^{6} \mathrm{~m}^{3}$ in 2000 from a total of $5.280 \times 10^{6} \mathrm{~m}^{3}$ in South Africa, has originated in reduced freshwater flow into the ocean in Mozambique, damaging the ecosystems and leading to saline intrusion (Ashton, 2003).

The shared nature of water resources in Africa, with more than 80 shared river basins and lakes and at least 60 transboundary aquifer systems, led to the establishment of various entities at national, sub-regional and regional levels for promotion of sustainable water resource management. Better management and development of water resources was also recognized in 2002 during the Johannesburg World Summit on Sustainable Development. Due to scarcity in this region, there is a need to pursue and adapt, in line with the Africa Water Vision for 2025 (UN WATER/AFRICA, 2009), more sustainable approaches for use and management of water resources, integrating aspects of water quantity and quality, surface and groundwater, climate change, and cultural aspects (Setegn and Donoso, 2015).

\subsection{Lack of infrastructure, financial resources and skills}

The lack of storage, treatment and piped water infrastructure can, even with abundant natural water resources, result in water 'being utilized neither effectively nor efficiently across many African countries (ACPC, 2013). As the costs of building new water infrastructure increase, together with the higher costs of operating and maintaining existing water infrastructure, funding for required investments in the sector becomes more difficult (Deloitte, 2016). Also the water quality of the sources for water supply is highly affected by untreated discharges due to improper sanitation (World Bank, 2011).

The most common types of sanitation infrastructure in many African cities are pit latrines and septic tanks, covering $60 \%-100 \%$ of the population (Nansubuga et al., 2016). In sub-Saharan Africa, only Angola, Botswana, Cabo Verde, Equatorial Guinea and South Africa have more than $70 \%$ coverage of improved sanitation - one that hygienically separates human excreta from human contact - with an average of $40 \%$ in 2015 (WHO/UNICEF, 2015). Furthermore, even the few existing central infrastructure systems in the region are generally not functioning at full capacity due to a lack of regular maintenance (Bahri et al., 2008). These very low levels of wastewater treatment have high negative impacts on receiving water bodies (Arsénio et al., 2018; Eckart et al., 2011) and on the health of the urban populations (Duflo et al., 2012).

African countries struggle to provide water and sanitation services mostly due to inefficiency in utilization of financial resources. In addition, misguided priorities in project development and infrastructure planning processes occur, where feasibility studies place more emphasis on technical feasibility rather than on the financial and institutional issues that are equally important or, in some cases, should precede the technical ones. Furthermore, projects in their conceptual stage do not always consider benefit maximization of the economic activities for where they are allocated, such as water storage, power generation, water reclamation applications, existing water supply systems and tourism. Tandi and Earle (2015) stated, therefore, that water-related infrastructure would be stronger if projects were conceptualized to serve multiple purposes.

\subsection{Possible solutions for alleviation of water scarcity}

The status quo regarding water and sanitation services has been insufficient, with many sub-Saharan countries presently experiencing physical water scarcity (Ashton and Turton, 2009; Wandiga, 2014) and with almost all countries expected to be in a state of water stress or scarcity within the next decade (UNEP, 2008).

The challenges could be overcome by implementing a combination of water demand management approaches together with use of other alternative water sources. 
Water demand management approaches have been proposed with the aim to conserve water by influencing its demand. This involves the application of selective incentives to promote efficient and equitable use of water. However, in urban centers of southern Africa, water demand management tends to fail due to a lack of data and a comprehensive information system to aid decision-making (Gumbo et al., 2003).

There is a major technical and organizational challenge for countries to launch rainwater harvesting and water conservation programs (Bixio et al., 2008), minimizing nonrevenue water through improved management and efficient use (Rached et al., 1996); implementing water reclamation schemes (Bixio et al., 2005); and studying and developing other sources such as groundwater (Pavelic et al., 2012), seawater (Frost and Sulivan, 2008) and (managed) aquifer recharge (Tredoux et al., 2002). Where feasible, transfer of water from those regions with excess water to the waterdeficient regions can also be an option (Setegn and Donoso, 2015).

Nansubuga et al. (2016) argued that in particular, resource recovery, e.g., through water reclamation programs, is a pivotal strategy for wastewater management in sub-Saharan Africa.

\section{Discussion}

\subsection{Development of water reclamation projects for industrial use}

The potential for water reclamation around the world is high, since sewage is available, technology and legislation regarding water savings exist, and people and industries are potentially interested. Projects implemented around the world illustrate the existence of functional methodologies for water reclamation and strategies and programs, acknowledging the beneficial role of water reclamation (Salgot and Huertas, 2006).

Although the driving forces for water reclamation differ, according to the socioeconomic context or the circumstances that lead to the successful implementation of a project, it can be noted that it is potentially possible to combine different experiences and create a baseline that can help to implement new projects. In this way, water reclamation for industries can play an important role in addressing water scarcity, giving industries the responsibility of not competing with the available water resources for domestic use and, in many cases, resulting in financial benefits (Grobicki, 2008). By using reclaimed water in industry, additional water will be available for drinking and other domestic purposes. From an economic perspective, it is important to have a clear view on the purpose of evaluating the costs of water reclamation installations. This can be focused on determining the charges to water users, the ways to finance the project, or assessing the wider economic performance of the investment, includ- ing the value of environmental impacts (Indian Institute of Technology, 2011).

From a social point of view, there is a need to examine the public attitude towards the idea of using reclaimed water. Although there are not many examples where industries reject the idea of reclaiming water, a low adoption rate was found in Thailand; despite the country's intention for industries to adopt water reclamation practices, only $10.5 \%$ of the industries included in the survey accepted the reclamation of the treated wastewater (Visvanathan and Cippe, 1999).

Understanding the drivers for and against water reclamation can facilitate efforts to meet associated policy goals. In Europe, the Urban Waste Water Treatment Directive (91/271/EEC) advises the use of reclaimed water "where appropriate", but the "appropriateness" is not defined (Hochstrat et al., 2006). Similarly, in 2007 the Australian federal government set a national target to reclaim $30 \%$ of Australia's sewage by 2015 (Marsden Jacob Associates, 2008) but did not articulate selection criteria for prioritizing investments. Given the lack of clear criteria, many different factors can influence whether or not water reclamation projects are actually implemented.

\subsection{Potential for successful implementation of water reclamation for industries in sub-Saharan Africa}

In literature, information about water reclamation schemes in sub-Saharan Africa is scarce. Most of the examples of reclaimed water are related to agriculture (Jiménez et al., 2010), with the exception of Namibia, directly producing drinking water from treated wastewater (Lahnsteiner and Lempert, 2007), and South Africa, using water reclamation for some industries (Table 4; Eckart et al., 2011; Adewumi et al., 2010). Even data of produced wastewater reported in this region include only a few countries; e.g., in the period from 2008 to 2012 only 13 of the 48 countries had partial reported volumes (Fao (Aquastat), 2012), and only three countries, Senegal, Seychelles and South Africa, had complete information on wastewater generation and treatment and reclaimed water available (Sato et al., 2013).

Water reclamation in industry is already practiced around the world, supported by advanced treatment technologies. However, reclaimed water is still not extensively explored as an alternative reliable source of water supply in sub-Saharan countries. The slow adoption reveals that the controversy around reclaimed water extends beyond just engineering and economics; many additional barriers such as governance issues and a lack of infrastructure, financial resources, and technical skills for operation and maintenance must be overcome to reclaim water for industry in this region.

One of these barriers is that water is underpriced, and most companies are subsidized by municipal or regional authorities (Banerjee et al., 2008). This situation leads to inefficient use of already scarce water resources and negatively influences the market for water reclamation initiatives. Subsidized 
prices not only tend to discourage proper use of water among those who often could afford to pay more but may also reduce the incentive for investment in sewage treatment and water reclamation. However, the example of eThekwini, where the concept of "water fit for purpose" has been implemented in the city of Durban, South Africa, shows that water reclamation in industry can be an alternative to respond to a conflict between water demand for domestic use and economic development under conditions of water scarcity (Adewumi et al., 2010).

The possibilities for the use of reclaimed water in industry should mainly be explored for mineral extraction, cooling in thermal power plants, and in other non-food manufacturing industries such as metal processing (aluminium, coper, iron and steel), paper, textile, chemicals and construction. According to Table 2, these industries especially use water for cooling processes and as boiler make-up, and in the case of minerals and construction, water is used for washing and processes, respectively.

Future infrastructure developments should include the design of systems that allow for the implementation of water reclamation with appropriate solutions for the local conditions. Particularly in sub-Saharan Africa, the selection of the treatment technology according to local experience and skills is important (Adewumi et al., 2010), including plans that allow for closing cycles, resource recovery and synergy options. The design of these systems should comprise a multiobjective optimization methodology for efficient use of resources (Eckart et al., 2011).

In addition, infrastructure planning, including sanitary infrastructure and industrial parks, should consider technological options taking into account all potential sources of water as a water resource appropriately matched to its end use and involving all stakeholders over the planning cycles. This means that additional costs have to be considered, and not only the water utilities should be included in the planning process (WERF, 2010).

Finally, an appropriate business model for industrial use of water, including all aspects of sustainability in water use, should be considered.

Industrial water users are firstly concerned with profitability and operating sustainability of their businesses (WBCSD - IWA, 2009). Therefore, when planning to implement water reclamation programs, the main factors that hinder the use of this water (e.g., water quantity and quality requirements, techno-economic considerations, service reliability, and risk assurance) should be considered. The most decisive factors are the availability of water resources, their accessibility, the distance between the production and the point of use, and the existence of treatment facilities. Other major factors include the general infrastructure, climatic conditions, other economic sectors (such as industry, tourism, etc.), institutional landscape (governmental and private), policy and strategy in the water sector, enforcement of legislation, general income level of the population, existing water tariff structures, and/or governmental subsidies (FEMIP, 2009).

\section{Concluding remarks}

The implementation of water reclamation in sub-Saharan Africa is lagging behind. Factors such as the increased demand for water, coupled with increased water stress, water scarcity, climate change and compliance measures towards environmental legislation, are likely to be drivers for use of reclaimed water in industries.

However, the sub-Saharan African region is characterized as not only by its water scarcity but also as being scarce in data and information, given a lack of well-developed sewer infrastructure and a low level of education on aspects related to water reclamation, usually with low water tariffs and legislation that, in most countries, are not being enforced. Therefore, the crucial steps to implement water reclamation should involve further practical research both on technical and governance aspects.

Industries with potential for use of reclaimed water should be identified, and the industrial water use locations and patterns should be evaluated. In addition, sewage flows available for reclamation should be identified to find links for incorporation of water reclamation in urban and industrial planning. Furthermore, the required water quality for industrial applications, compared to the quality of sewage, or effluents of wastewater treatment plants, should be determined to be able to design appropriate (low cost) water treatment solutions for water reclamation for industrial purposes.

Parallel to the technical challenges, possibilities for changing legislation or introducing of new policies where they do not exist should be assessed next to the adoption of alternative financial structures and subsidies that support water reclamation. In particular, the involvement of stakeholders should be analyzed to study the acceptance of water reclamation for industrial uses and the inclusion of water reclamation options in integrated water and sanitation infrastructure planning.

These together will, in the end, lead to a higher availability of water for both domestic and industrial purposes, increasing the chances for economic growth and growth of urban health and well-being.

Data availability. The research data of this work can be obtained by contacting the corresponding author.

Author contributions. All authors contributed to the definition of the purpose of this review, suggested the important aspects to be included, and contributed to the writing of the paper. 
Competing interests. The authors declare that they have no conflict of interest.

Acknowledgements. Authors would like to acknowledge NWO and Nuffic for funding this research.

Review statement. This paper was edited by Ran Shang and reviewed by Nityanand Singh Maurya and one anonymous referee.

\section{References}

ACPC: Climate Change and Water in Africa: Challenges, Opportunities and Recommendations, available at: http://www. climdev-africa.org (last access: 20 July 2019), 2013.

Adewumi, J. R., Ilemobade, A. A., and Van Zyl, J. E.: Treated wastewater reuse in South Africa: Overview, potential and challenges, Resour. Conserv. Recy., 55, 221-231, https://doi.org/10.1016/j.resconrec.2010.09.012, 2010.

Almeida, G., Vieira, J., Marques, A. S., Kiperstok, A., and Cardoso, A.: Estimating the potential water reuse based on fuzzy reasoning, J. Environ. Manage., 128, 882-892, https://doi.org/10.1016/j.jenvman.2013.06.048, 2013.

AMCOW: 2012 Status Report on the Application of Integrated Approaches to Water Resources Management in Africa, edited by: McMulen, C., available at: https://www.un.org/ waterforlifedecade/pdf/un_water_status_report_2012.pdf (last access: 20 July 2019), 2012.

Anderson, J.: The environmental benefits of water recycling and reuse, Water Sci. Tech.-W. Sup., 3, 1-10, 2003.

Angelakis, A. N. and Gikas, P.: Water reuse: Overview of current practices and trends in the world with emphasis on EU states, Water Util. J., 8, 67-78, 2014.

Apostolidis, N., Hertle, C., and Young, R.: Water Recycling in Australia, Water, 3, 869-881, https://doi.org/10.3390/w3030869, 2011.

Arsénio, A. M., Salim, I. C., Hu, M., Matsinhe, N. P., Scheidegger, R., and Rietveld, L.: Mitigation potential of sanitation infrastructure on groundwater contamination by nitrate in maputo, Sustain., 10, 1-18, https://doi.org/10.3390/su10030858, 2018.

Asano, T.: Wastewater Reclamation and Reuse, CRC Press, Florida, 1998.

Asano, T.: Urban water recycling, Water Sci. Technol., 51, 83-89, 2005.

Asano, T. and Jimenez, B.: Water Reuse: An International Survey of current practice, issues and needs, IWA Publishing, London, 2008.

Asano, T. and Visvanathan, C.: Industries and water recycling and reuse, in: Founders Seminar, p. 10, Norra latin., 2001.

Ashton, P.: Southern African Water Conflicts: Are They Inevitable or Preventable?, Pretoria., 2003.

Ashton, P. and Turton, A.: Water and Security in Sub-Saharan Africa: Emerging Concepts and their Implications for Effective Water Resource Management in the Southern African, in: Facing Global Environmental Change, edited by: Brauch, H. G., Spring, Ú. O., Grin, J., Mesjasz, C., Kameri-Mbote, P., Behera, N. C., Chourou, B., and Krummenacher, H., 661-674, 2009.
Bahri, A., Drechsel, P., and Brissaud, F.: Water reuse in Africa: challenges and opportunities, available at: https://cgspace.cgiar.org/ handle/10568/38135 (last access: 16 November 2016), 2008.

Baker, J.: ICIS Innovation Awards: Dow Chemical wins CSR category, available at: http:// www.icis.com/resources/news/2008/10/13/9162810/ icis-innovation-awards-dow-chemical-wins-csr-category/ (last access: 27 July 2016), 2008.

Banerjee, S., Skilling, H., Foster, V., Briceño-Garmendia, C., Morella, E., and Chfadi, T.: Africa Infrastructure Country Diagnostic: Urban Water Supply in Sub-Saharan Africa, available at: http://www.eu-africa-infrastructure-tf.net/attachments/ library/aicd-background-paper-12-water-summary-en.pdf (last access: 20 July 2019), 2008.

Bendahmane, D.: Water reuse in developing countries, Virginia, available at: https://www.ircwash.org/sites/default/files/ 351.0-93WA-10841.pdf (last access: 20 July 2019), 1992.

Mudgal, S., Van Long, L., Haines, R., McNeil, D., Jeffrey, P., Smith, H., and Knox, J.: Optimising water reuse in the EU-Final report prepared for the European Comission (DG ENV), Part 1. in colaboration with ICF and Cranfield University, 2015.

Bixio, D., Cikurel, H., Muston, M., Miska, V., Joksimovic, D., Ravazzini, A., Aharoni, A., Savic, D., Thoeye, C., Building, H., and Road, N. P.: Municipal wastewater reclamation: where do we stand?? An overview of treatment technology and management practice, Water Sci. Tech.-W. Sup., 5, 77-86, 2005.

Bixio, D., Thoeye, C., Wintgens, T., Ravazzini, A., Miska, V., Muston, M., Chikurel, H., Aharoni, A., Joksimovic, D., and Melin, T.: Water reclamation and reuse: implementation and management issues, Desalination, 218, 13-23, https://doi.org/10.1016/j.desal.2006.10.039, 2008.

Bouabid, A. and Louis, G. E.: Capacity factor analysis for evaluating water and sanitation infrastructure choices for developing communities, J. Environ. Manage., 161, 335-343, https://doi.org/10.1016/j.jenvman.2015.07.012, 2015.

Chen, W., Bai, Y., Zhang, W., Lyu, S., and Jiao, W.: Perceptions of different stakeholders on reclaimed water reuse: The case of Beijing, China, Sustainability, 7, 9696-9710, https://doi.org/10.3390/su7079696, 2015.

Chhipi-Shrestha, G., Rodriguez, M., and Sadiq, R.: Selection of sustainable municipal water reuse applications by multi- stakeholders using game theory, Sci. Total Environ., 650, 2512-2526, https://doi.org/10.1016/j.scitotenv.2018.09.359, 2019.

Conway, D., van Garderen, E. A., Deryng, D., Dorling, S., Krueger, T., Landman, W., Lankford, B., Lebek, K., Osborn, T., Ringler, C., Thurlow, J., Zhu, T. J., and Dalin, C.: Climate and southern Africa's water-energy-food nexus, Nat. Clim. Change, 5, 837846, https://doi.org/10.1038/Nclimate2735, 2015.

Cooperman, A., Dieckmann, J., and Brodrick, J.: Power Plant Water Use, ASHRAE J., 54, 65-68, 2012.

Cornejo, P. K., Zhang, Q., and Mihelcic, J. R.: How does scale of implementation impact the environmental sustainability of wastewater treatment integrated with resource recovery?, Environ. Sci. Technol., Technol., 50, 6650-6689, https://doi.org/10.1021/acs.est.5b05055, 2016.

Deloitte: Africas Changing Infrastructure Landscape: Africa Construction Trent Report, Belgium, 2016. 
de Wit, M.: Changes in Surface Water Supply Across Africa with Predicted Climate Change, Science, 311, 1917-1921, https://doi.org/10.1126/science.1119929, 2006.

Donkor, S. M. K. and Wolde, Y. E.: Integrated water resources management in Africa: Issues and options, in: Integrated Wetlands and Water Resources Management, edited by: Bergkamp, G., Pirot, J.-Y., and Hostettler, S., 1-14, IUCN-The World Conservation Union, Dakar, 1998.

Duflo, E., Galiani, S., and Mobarak, M.: Improving Access to Urban Services for the Poor: Open Issues and a Framework for a Future Research Agenda, Cambridge, available at: https://www.povertyactionlab.org/sites/default/files/ publications/USIReviewPaper.pdf (last access: 20 July 2019), 2012.

Jacobsen, M., Webster, M., and Vairavamoorthy, K.: The Future of Water in African Cities: Why Waste Water?, Washington, DC., 2013.

Emanuel, E.: International best Practice-International Overview of Best Practices in Wastewater Management, Kingston, 2010.

Eslasmain, S.: Urban Water Reuse Handbook, 1st ed., CRC Press, 2016.

European Commission: Integrated pollution prevention and control. Reference document on best available techniques for the textiles industry, available at: http://eippcb.jrc.ec.europa.eu/reference/ (last access: access 20 July 2019), 2003.

EUROSTAT: Water use in industry, available at: https://ec. europa.eu/eurostat/statistics-explained/index.php?title=Archive: Water_use_in_industry (last access: 3 June 2016), 2014.

Fao (Aquastat): AQUASTAT database Database Query Results, Food Agric. Organ., 2011, available at: http://www. fao.org/nr/water/aquastat/data/query/results.html (last access: 20 July 2019), 2012.

FEMIP: Identification and Removal of Bottlenecks for extended Use of Wastewater for Irrigation or for other Purposes, Luxemburg, 2009.

Freedman, J. and Enssle, C.: Addressing Water Scarcity Through Recycling and Reuse: A Menu for Policymakers, available at: http://smartcitiescouncil.com/resources/ addressing-water-scarcity-through-recycling-and-reuse-menu-policy (last access: 12 September 2019), 2015.

Frost \& Sullivan: Water issues kindle interest in desalination and drive equipment markets in Africa, Membr. Technol., 2008, 1011, 2008.

Giurco, D., Bossilkov, A., Patterson, J., and Kazaglis, A.: Developing Industrial Water Reuse Synergies In Port Melbourne: CostEffectiveness, Barriers And Opportunities, J. Clean. Prod., 19, 867-876, https://doi.org/10.1016/j.jclepro.2010.07.001, 2010.

Government of Karnakata: Institutional strengthening \& Sector Inventory for PPP Mainstreaming in Directorate of Municipal Administration, Noida, 2012.

Grobicki, A.: The Future of Water Use in Industry, World Water, available from: https://sswm.info/sites/default/files/reference attachments/GROBICKInyTheFutureofWaterUseinIndustry.pdf, (last acess: 12 September 2019), 2008.

Gumbo, B., Juizo, D., and van der Zaag, P.: Information is a prerequisite for water demand management: Experiences from four cities in Southern Africa, Phys. Chem. Earth, 28, 827-837, https://doi.org/10.1016/j.pce.2003.08.010, 2003.
GWI: Municipal Water Reuse Markets 2010, Media Analytics Limited, 2010.

Hess, T. M., Sumberg, J., Biggs, T., Georgescu, M., HaroMonteagudo, D., Jewitt, G., Ozdogan, M., Marshall, M., Thenkabail, P., Daccache, A., Marin, F., and Knox, J. W.: A sweet deal? Sugarcane, water and agricultural transformation in Sub-Saharan Africa, Global Environ. Chang., 39, 181-194, https://doi.org/10.1016/j.gloenvcha.2016.05.003, 2016.

Hochstrat, R., Wintgens, T., Melin, T., and Jeffrey, P.: Assessing the European wastewater reclamation and reuse potential - a scenario analysis, Desalination, 188, 1-8, 2006.

Holden, J. (Ed.): Water Resources: An Integrated Approach, 1 st., Routledge, 2013.

IPCC: Reference Document on Best Available Techniques in the Ferrous Metals Processing Industry, 2001.

IMF: Issues in managing water challenges and Policy Instruments: Regional Perspectives and Case Studies, 1-22, 2015.

Indian Institutes of Technology: Review of Wastewater Reuse Projects Worldwide, Collation of Selected International Case Studies and Experiences, Kanpur, 2011.

Institute Water for Africa: Water Consumption in Africa, available at: https://water-for-africa.org/en/water-consumption/articles/ water-consumption-in-africa.html, last access: 25 September 2016.

Jiménez, B., Drechsel, P., Koné, D., Bahri, A., Raschid-Sally, L., and Qadir, M.: Wastewater, Sludge and Excreta Use in Developing Countries: An Overview, in: Wastewater irrigation and health: assessing and mitigating risk in low-income countries, edited by: Drechsel, P., Scott, C. A., Raschid-Sally, L., Redwood, M., and Bahri, A., 3-27, International Development Research Centre (IDRC), International Water Management Institute (IWMI), London, Ottawa, Colombo, Sri Lanka, 2010.

Jiménez-Cisneros, B.: Water Reuse and Recycling, Compr. Water Qual. Purif., 3, 296-323, https://doi.org/10.1016/B978-0-12382182-9.00054-2, 2014.

Jimenez Cisneros, B.: Water Recycling and Reuse: An Overview, in Water Reclamation and Sustainability, edited by: Ahuja, S., 431-454, Elsevier, Paris, 2014.

riangensa, R. M. and Kamusoko, R.: Temporal and spatial analysis of electricity generation from biomass sources in sub-Saharan Africa, Cogent Eng., 4, 1-11, https://doi.org/10.1080/23311916.2017.1296757, 2017.

Joint Research Council: Integrated Pollution Prevention and Control (IPPC) Reference Document on the application of Best Available Techniques to Industrial Cooling Systems, available at: http://eippcb.jrc.ec.europa.eu/reference/BREF/cvs_bref_ 1201.pdf (last access: 20 July 2019), 2001.

Kennedy, L. A. and Tsuchihashi, R.: Is Water Reuse Sustainable? Factors Affecting its Sustainability, Arab. J. Sci. Eng., 30, 3-15, 2005.

Kerstens, S. M., Hutton, G., Firmansyah, I., Leusbrock, I., and Zeeman, G.: An Integrated Approach to Evaluate Benefits and Costs of Wastewater and Solid Waste Management to Improve the Living Environment: The Citarum River in West Java, Indonesia, J. Environ. Prot., 7, 1439-1465, https://doi.org/10.4236/jep.2016.711122, 2016.

Kossar, M. J.: Proposal for water reuse in the Kraft pulp and paper industry, Water Pract. Technol., 8, 359-374, https://doi.org/10.2166/wpt.2013.036, 2013. 
Lahnsteiner, J. and Klegraf, F.: Industrial Water Reuse Case Studies, IWA Newsl. Spec. Gr. Water Reuse, November, 0-3, 2005.

Lahnsteiner, J. and Lempert, G.: Water management in Windhoek, Namibia, Water Sci. Technol., 55, 441-448, https://doi.org/10.2166/wst.2007.022, 2007.

Lahnsteiner, J. and Mittal, R.: Reuse and recycling of secondary effluents in refineries employing advanced multibarrier systems, Water Sci. Technol., 62, 1813-1820, https://doi.org/10.2166/wst.2010.520, 2010.

Lautze, J., Stander, E., Drechsel, P., da Silva, A. K., and Keraita, B.: Resource Recovery and Reuse series 4: Global Experiences in Water Reuse, Battaramulla, 2014.

Lazarova, V.: Wastewater Treatment for Water Recycling, Water, 30, 164-234, 2005.

Lazarova, V., Sturny, V., and Sang, G. T.: Relevance and benefits of urban water reuse in tourist areas, Water, 4, 107-122, https://doi.org/10.3390/w4010107, 2012.

Lazarova, V., Asano, T., Bahri, A., and Anderson, J.: Milestones in Water Reuse: The Best Success Stories, IWA Publishing, 2013.

Lee, H. and Tan, T. P.: Singapore's experience with reclaimed water: NEWater, Int. J. Water Resour. Dev., 0627, 1-11, https://doi.org/10.1080/07900627.2015.1120188, 2016.

Lens, P., Pol, L. H., Wilderer, P., and Asano, T.: Water Recycling and Resource Recovery in Industry: analysis, technologies and implementation, IWA Publishing, London, 2002.

Li, W.-W., Yu, H.-Q., and Rittmann, B. E.: Reuse water pollutants, Nature, 528, 29-31, https://doi.org/10.1038/528029a, 2015.

Lloyd Owen, D. A.: Public-private partnerships in the water reuse sector: a global assessment, Int. J. Water Resour. Dev., 32, 1-10, https://doi.org/10.1080/07900627.2015.1137211, 2016.

Marecos do Monte, M. H.: Water Reuse in Europe, E-WAter, 1-18, https://doi.org/10.2788/29234, 2007.

Marsden Jacob Associates: National Snapshot of Current and Planned Water Recycling and Reuse Rates, available at: http://www.environment.gov.au/water/publications/urban/pubs/ national-recycling-snapshot.pdf, (last access: 20 July 2019), 2008.

Meneses, Y. E., Stratton, J., and Flores, R. A.: Water reconditioning and reuse in the food processing industry: Current situation and challenges, Trends Food Sci. Tech., 61, 72-79, https://doi.org/10.1016/j.tifs.2016.12.008, 2017.

Miller, G. W.: Integrated concepts in water reuse: Managing global water needs, Desalination, 187, 65-75, https://doi.org/10.1016/j.desal.2005.04.068, 2006.

Moed, D. H.: Organic Contaminants and Treatment Chemicals in Steam-Water Cycles, Delft University of Technology, 2015.

Molinos-Senante, M., Hernandez-Sancho, F., and Sala-Garrido, R.: Tariffs and Cost Recovery in Water Reuse, Water Resour. Manag., 27, 1797-1808, https://doi.org/10.1007/s11269012-0111-4, 2013.

Nansubuga, I., Banadda, N., Verstraete, W., and Rabaey, K.: A review of sustainable sanitation systems in Africa, Rev. Environ. Sci. Bio, https://doi.org/10.1007/s11157-016-9400-3, 2016.

National Academy: Water Reuse: Potential for Expanding the Nation's Water Supply Through Reuse of Municipal Wastewater, Washington, DC., 2012.

Nazari, R., Eslamian, S., and Khanbilvardi, R.: Water Reuse and Sustainability, in Ecological Water Quality - Water Treatment and Reuse, edited by: Voudouris, D., 241-
254, In Tech, available at: http://www.intechopen.com/ books/ecological-water-quality-water-treatment-and-reuse/ water-reuse-and-sustainability (last access: 20 July 2019), 2012.

NWRS: Annexure D National Satrategy for Water re-use, Pretoria, 2011.

Ordóñez, R., Hermosilla, D., Merayo, N., Gascó, A., Negro, C., and Blanco, Á.: Application of Multi-Barrier Membrane Filtration Technologies to Reclaim Municipal Wastewater for Industrial Use, Sep. Purif. Rev., 43, 263-310, https://doi.org/10.1080/15422119.2012.758638, 2014.

Pavelic, P., Giordano, M., Keraita, B., Ramesh, V., and Rao, T.: Groundwater availability and use in sub-Saharan Africa: A review of 15 countries, Colombo, 2012.

Po, M., Kaercher, J. D., and Nancarrow, B. E.: Literature Review of Factors Influencing Public Perceptions of Water Reuse, 1-44, 2003.

PUB: A Fine Balance - Annual Report, Singapore, 2014.

Rached, E., Rathgeber, E., and Brooks, D. B.: Water Management in Africa and Meadle East, International Development Research Centre (IDRC), Canada, 1996.

Ranade, V. V. and Bhandari, V. M.: Industrial Wastewater Treatment, Recycling, and Reuse: An Overview, in Industrial Wastewater Treatment, Recycling and Reuse, 1-80, Elsevier Ltd., 2014.

Rietveld, L. C., Norton-Brandão, D., Shang, R., van Agtmaal, J., and van Lier, J. B.: Possibilities for reuse of treated domestic wastewater in The Netherlands, Water Sci. Technol., 64, 1540, https://doi.org/10.2166/wst.2011.037, 2011.

Rietveld, L. C., Siri, J. G., Chakravarty, I., Arsénio, A. M., Biswas, R., and Chatterjee, A.: Improving health in cities through systems approaches for urban water management, Environ. Heal., 15, 151-171, https://doi.org/10.1186/s12940-016-0107-2, 2016.

Ryan, S.: Europe moves forward on water reuse, World Water Water reuse Desalin., Spring, 11-13, 2016.

Salgot, M. and Folch, M.: Wastewater treatment and water reuse, Curr. Opin. Environ. Sci. Heal., 2, 64-74, https://doi.org/10.1016/j.coesh.2018.03.005, 2018.

Salgot, M. and Huertas, E.: Integrated Concepts for Reuse of Upgraded Wastewater, 1st ed., Springer, 2006.

San Jose Environmental Service Department: Guidelines for Managing Water in Cooling Systems for Owners, Operators, and Environmental Managers, San Jose, 2002.

Sapkota, A. R.: Editorial: Water reuse, food production and public health: Adopting transdisciplinary, systemsbased approaches to achieve water and food security in a changing climate, Environ. Res., 171, 576-580, https://doi.org/10.1016/j.envres.2018.11.003, 2019.

Sato, T., Qadir, M., Yamamoto, S., Endo, T., and Zahoor, A.: Global, regional, and country level need for data on wastewater generation, treatment, and use, Agr. Water Manage., 130, 1-13, https://doi.org/10.1016/j.agwat.2013.08.007, 2013.

Schaefer, K., Exall, K., and Marsalek, J.: Water Reuse and Recycling in Canada: A Status and Needs Assessment, Can. Water Resour. J., 29, 195-208, https://doi.org/10.4296/cwrj195, 2004.

Sensorex: Boiler Water Treatment, available at: https: //www.sensorex.com/boiler-water-treatment/ (last access: 22 May 2017), 2016.

Setegn, S. G. and Donoso, M. C.: Sustainability of integrated water resources management: Water governance, climate and ecohydrology, in: Sustainability of Integrated Water Resources Man- 
agement: Water Governance, Climate and Ecohydrology, 25-49, 2015.

Smith, C.: Reclaimed Water for Industrial Uses, 2015.

Smith, T.: Overcoming Challenges in Wastewater Reuse: A Case Study of San Antonio, Texas, Harvard University, 2011.

Tadross, M. and Johnston, P.: Climate Change Projections for Maputo: Adding value through downscaling, Cape Town, 2012.

Tandi, N. and Earle, A.: Financing water infrastructure in Africa The infrastructure financing gap in Africa - what's stopping us?, Stokholm, available at: https://www.siwi.org/publications/ financing-water-infrastructure-in-africa/, (last acess: 16 September 2019), 2015.

Tanik, A., Sarikaya, H., Eroglu, V., Orhon, D., and Ozturk, I.: Potential for reuse of treated effluent in Istanbul, Water Sci. Technol., 33, 107-113, https://doi.org/10.1016/0273-1223(96)00412X, 1996.

Toze, S.: Reuse of effluent water - Benefits and risks, Agr. Water Manage., 80, 147-159, https://doi.org/10.1016/j.agwat.2005.07.010, 2006.

Tredoux, G., Murray, E., and Cave, L.: Infiltration basins and other recharge systems in Southern Africa, in: Management of Aquifer Recharge and Subsurface Storage Seminar. Making Better use of Our Largest Reservoir, 67-77, 2002.

UNEP: Water and Wastewater Reuse - An Environmentally Sound Approach for Sustainable Urban Water Management, http://hdl. handle.net/20.500.11822/8390 (last access: 20 July 2019), 2005.

UNEP: An overview of the state of the World's Fresh and Marine Waters, available at: http://hdl.handle.net/20.500.11822/20624 (last access: 5 June 2016), 2008.

UN WATER/AFRICA: The Africa Water Vision for 2025: Equitable and Sustainable Use of Water for Socioeconomic Development, Econ. Comm. Africa, 1-34, 2009.

USEPA: Guidelines for Water Reuse, available at: http://nepis. epa.gov/Exe/ZyPURL.cgi?Dockey=30004JK8.txt (last access: 16 September 2019), 1992.

USEPA: Guidelines for Water Reuse, EPA/625/R-04/108, 2004.

USEPA: Guidelines for Water Reuse, 252, available at: http://nepis. epa.gov/Adobe/PDF/P100FS7K.pdf (last access: 16 September 2019), 2012.

Van der Bruggen, B.: Chapter 3 The Global Water Recycling Situation, in Sustainability Science and Engineering, vol. 2, edited by: Abraham, M. A., 41-62, Elsevier Science, 2010.
Vigneswaran, S. and Sundaravadivel, M.: Recycle and reuse of domestic wastewater, Encycl. Life Support Syst., 1, 1-29, 2009.

Visvanathan, C. and Asano, T.: the Potential for Industrial Wastewater Reuse, in Wastewater Recycling, Reuse, and Reclamation, edited by: Vigneswaran, S., p. 14, EOLSS Publications, 2009.

Van Agtmaal, J., de Boks, P. A., Cornips, R., and Paping, L. L. M. J.: Evaluation of feed water sources and retrofitting of an Integrated Membrane System, in: 6th IWA Specialist Conference on Wastewater Reclamation and Reuse for Sustainability, 1-7, IWA, Antwerpen, 2007.

Van der Watt, T.: Good Neigbour agreements on South Africa's shared Watercourses, Water Wheel, 2003.

Van Koppen, B.: Water reform in Sub-Saharan Africa: What is the difference?, Phys. Chem. Earth, 28, 1047-1053, https://doi.org/10.1016/j.pce.2003.08.022, 2003.

Wandiga, S. O.: Comprehensive Water Quality and Purification, Elsevier, 2014.

Water for Life: 2006 Metropolitan Water Plan, Sydney, available at: http://www.waterforlife.nsw.gov.au/p/wfl2006.pdf (last access: 16 September 2019), 2006.

WBCSD - IWA: Industrial Water Re-use Opportunities - Scoping Paper, DRAFT, 2009.

WERF: Sustainable Integrated Water Resources Management State of Knowledge, 2010.

WHO/UNICEF: 25 YEARS Progress on Sanitation and Drinking Water: 2015 Update and MDG Assessment, New York, NY UNICEF World Heal. Organ., 4, ISBN 978924150914 5, 2015.

World Bank: Africa's Emerging Urban Water, in: The Future of Water in African Cities, 15-40, 2011.

World Bank: World Development Indicators: Freshwater, 2015.

Yager, T. R.: 2013 Minerals Yearbook Mozambique, edited by: USGS, Virginia: USGS, 2016.

Yerri, S. and Piratla, K. R.: Decentralized water reuse planning?: Evaluation of life cycle costs and bene fi ts, Resour. Conserv. Recycl., 141, 339-346, https://doi.org/10.1016/j.resconrec.2018.05.016, 2019. 